\author{
V. Tihenko, V. Lebedev, \\ T. Chumachenko, Odessa, Ukraine

\section{AUTOMATIC CONTROL OF TEMPERATURE AND POWER CONDITIONS DURING ROUGH GRINDING OF SLABS}

\begin{abstract}
The production of high-quality rolled products (slabs), the formation of its surface phasestructural composition, texture, stress state during rough grinding depends on the temperature in the area of contact between the wheel and the slab. During processing, due to geometric errors of the rolled surface, as well as due to local changes in hardness, periodic fluctuations of the instantaneous depth of cut occur, which can be determined indirectly by controlling one of the technological parameters, for example, the power spent on grinding, with subsequent recalculation it to online temperature values. The grinding temperature is described as a control object in the form of an aperiodic link. Computer simulation has confirmed the efficiency of the system for maintaining the specified temperature of slab grinding under various operating conditions that simulate the situations of real production.
\end{abstract}

Keywords: rough grinding; slab grinding temperature control; aperiodic link.

\title{
Introduction.
}

A significant part of Ukrainian exports are still products of the metallurgical industry, including rolled products.

When supplying metal products for export, Ukrainian metallurgical enterprises face tough competition from foreign manufacturers.

To obtain high-quality rolled products, the surface layer of billets (slabs) containing small cracks, cavities and scale must be cleaned right in the shops of metallurgical enterprises. The output of mill scale is on average $1-3 \%$ of the mass of finished rolled products.

There are various methods of cleaning (chemical, electrochemical and mechanical), however, in many cases, the processing of the surface layer with abrasive wheels on a roughing and grinding machine is used.

Rough grinding machines differ significantly from grinding machines for general machine-building use in terms of technological requirements for them. This difference lies in the fact that they implement an "elastic" grinding scheme, in contrast to the "rigid" one on conventional grinding machines. "Elastic" grinding scheme - processing with a constant pressing force of the wheel to the rolled steel is intended for the implementation of the process of removing metal of constant thickness from the surface of the workpiece. In practice, inconsistency in the grinding depth is often observed, which is noticeable by changes in the width of the "line" being ground. 
The workpiece to be processed is fixed on a moving table, and a headstock with a grinding wheel is lowered onto it from above. The speed of the table with the workpiece can be varied in the range from 5 to $60 \mathrm{~m} / \mathrm{min}$. The clamping force of the grinding wheel during roughing can reach $10,000 \mathrm{~N}$.

Since metal defects are concentrated mainly in the surface layer of the workpieces, only the surface layer must be removed to reduce metal waste during peeling. This will reduce the unproductive consumption of expensive metal, which is especially important when roughing alloy steels.

In roughing and grinding machines, the control action can be exerted on the drive for the longitudinal movement of the table, however, the large masses of the table and the workpiece make this channel very inertial and not very suitable for the system for maintaining the grinding depth.

It is expedient to control the drive for moving the grinding head in the direction perpendicular to the surface to be treated.

The temperature arising in the contact area of the grinding wheel with the slab can reach $1200-1300^{\circ} \mathrm{C}$ and cause grinding defects (burns) - deep changes in the phase-structural composition of the surface layer, which creates favorable conditions for the formation of residual stresses and, as a result, cracks [1] ... As is known from the literature [2], thermal grinding defects reduce the durability by $3-$ 4 times. During processing, due to geometric errors of the slab surface, as well as due to local changes in hardness, periodic fluctuations of the instantaneous depth of cut occur, which causes periodic changes in the value of the contact temperature of grinding, as a result of which thermal defects of the surface layer can occur, such as phase and structural transformations that sharply reduce the performance of the surface layer.

The most rational way out of this situation is to automatically maintain the contact temperature of grinding at a safe level. This can be done by compensating for fluctuations in the depth of the cut with other components of the processing modes. Thus, the purpose of this work is to consider a mathematical model of the process of automatic control of the contact temperature of grinding the surface of slabs.

To achieve this goal, it is necessary to solve the following tasks: select a control object, select a controlled value, select control laws, develop an algorithm and a block diagram of the control process.

This task can be accomplished with the help of an analytical study of the process of heat generation during grinding, considering the process of cutting with an abrasive grain with its contradictory laws [3,5].

It would be more rational to choose the grinding temperature as a controllable value; however, practically insurmountable difficulties arise in the practical implementation of this choice. In order to obtain information about the grinding temperature of a particular slab at an arbitrary cutting moment, it is necessary that 
there is a temperature sensor in the grinding wheel, which cannot be installed in the wheel without violating the integrity of the latter, which cannot be done during the production process for safety reasons.

A large number of works have been devoted to the issues of adaptive control of the grinding process, however, the issue of controlling the temperature regime of grinding is practically not considered.

In the source [1] the authors consider the mathematical modeling of abrasive processing processes, in [2] the source describes the processes of temperature formation during grinding, in the work [3] discloses general issues and theoretical provisions of the adaptive control of the grinding process, in [4] the work considers adaptive feed control, [5] the work is devoted to general issues of adaptive control and optimization issues, [6] - issues of control and optimization of the external grinding process, in [7] - issues of adaptive control of metal-cutting machines, [8] the work is devoted to general issues of saving tools and increasing labor productivity in the use of adaptive control, in [9] the work considers the issue of controlling the transverse feed during grinding, in $[10,11]$ - the process of adaptive control of grinding forces, in [12] the work considers the effect of temperature fields of the grinding temperature on the stress state of the coatings applied to the part, but in The request for adaptive temperature control is not affected.

From the literature review, it can be concluded that the issues of controlling the grinding temperature have not yet been fully considered.

\section{Research Methodology.}

Information about the temperature value can be obtained indirectly by monitoring one of the technological parameters, for example, the power consumed for grinding, with its subsequent conversion into temperature values in the online mode. As shown in [2], the surface temperature during grinding can be related to the power by the following relationship

$$
\Theta=\frac{1,12 \cdot \eta \cdot Q \cdot \sqrt{\tau}}{\varepsilon \cdot F},
$$

where $\eta$ is a coefficient indicating what proportion of heat is transferred to the part; $\mathrm{Q}$ - grinding power, W; $\varepsilon$ - coefficient of thermal activity of the part, $\mathrm{J} / \mathrm{m}^{2} \mathrm{deg} \mathrm{s}^{0.5}$; $\mathrm{F}$ is the area of the contact patch of the wheel with the part, $\mathrm{m}^{2} ; \tau$ is the contact time of the wheel with an arbitrary point of the ground surface, sec.

After some transformations we have:

$$
\Theta=\frac{0,896 \cdot Q}{\sqrt{v_{s}} \cdot F \cdot \varepsilon} \text { or } \Theta=k \cdot Q,
$$




$$
k=\frac{0,896}{\sqrt{v_{s} \cdot F \cdot \varepsilon}}=\frac{0,896}{\sqrt{D \cdot t \cdot v_{s}} \cdot S \cdot \varepsilon}
$$

where $D$ is the diameter of the wheel, $\mathrm{m} ; t$ is the depth of grinding, $\mathrm{m} ; v_{s}$ - part speed, $\mathrm{m} / \mathrm{s} ; S$ - the value of the cross feed, $\mathrm{m}$.

The dependence of temperature on time during grinding is described by the expression [2]

$$
\Theta_{\tau}=\Theta_{\max }\left[1-\exp \left(-\frac{v_{u}^{2} \cdot \tau}{4 \cdot a}\right)\right],
$$

where $\Theta_{\max }$ - is the maximum temperature, ${ }^{\circ} \mathrm{C} ; v_{u}$ - speed of the heat source, $\mathrm{m} /$ $\mathrm{s} ; \tau$ is the current time, $\mathrm{s} ; a$ - coefficient of thermal diffusivity of the grinded material, $\mathrm{m}^{2} / \mathrm{s}$.

Assuming that the time constant of the temperature rise process is:

We have: $\quad \Theta_{\tau}=\Theta_{\max }\left(1-e^{-\frac{\tau}{T}}\right)$,

$$
\frac{4 a}{v_{u}^{2}}=T,
$$

and in operator form: $\quad \omega_{p}=\frac{\Theta_{\tau(p)}}{\Theta_{\max (p)}}=\frac{1}{T_{p}+1}$.

Thus, the grinding temperature in the control system can be represented as an aperiodic link.

In general, the block diagram of the control system can be as shown in Fig. 1.

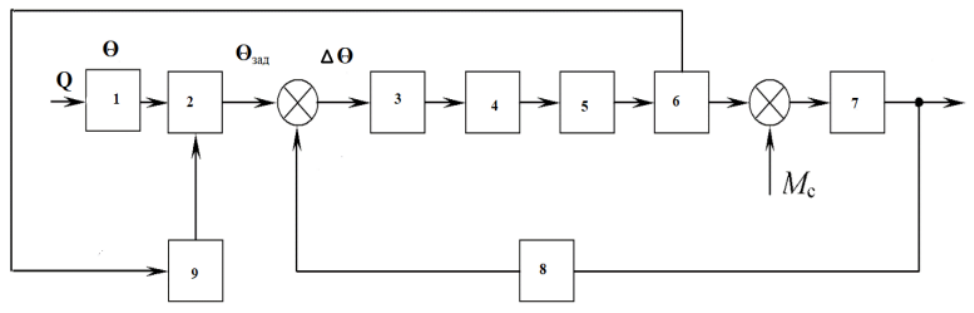

Figure 1 - Block diagram of the grinding temperature maintenance system 1 - block for converting power to temperature; 2 - grinding temperature regulator;

3 - amplifier; 4 - hydraulic valve with proportional control;

5 - hydraulic cylinder; 6 - processing process; 7 - grinding wheel drive;

8 - the sensor of the calculated temperature by power; 9 - table speed sensor 
The drive for the movement of the grinding head can be pneumatic or hydraulic, but the hydraulic drive has higher dynamic properties.

A fragment of the hydraulic circuit of the drive is shown in Fig. 2 (a). For experimental verification of the characteristics of the control system, a special stand was used (Fig. 2 (b)), which consisted of a welded portal and a rotary frame, the flywheel masses of which corresponded to the reduced flywheel masses of the machine spindle drive.

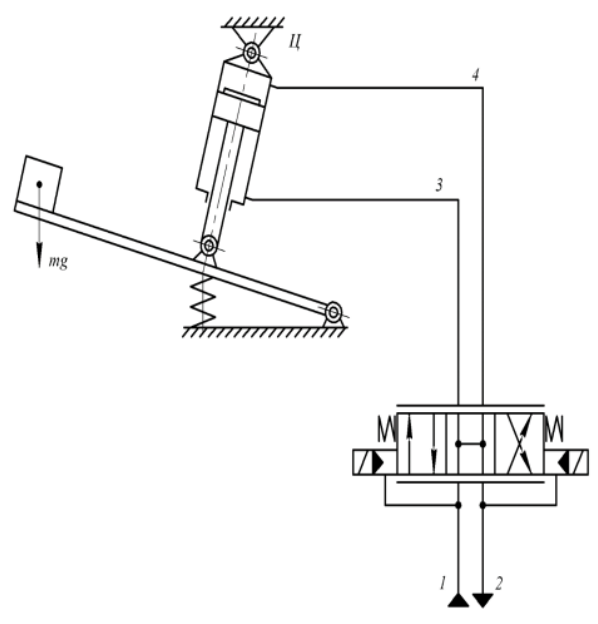

a)

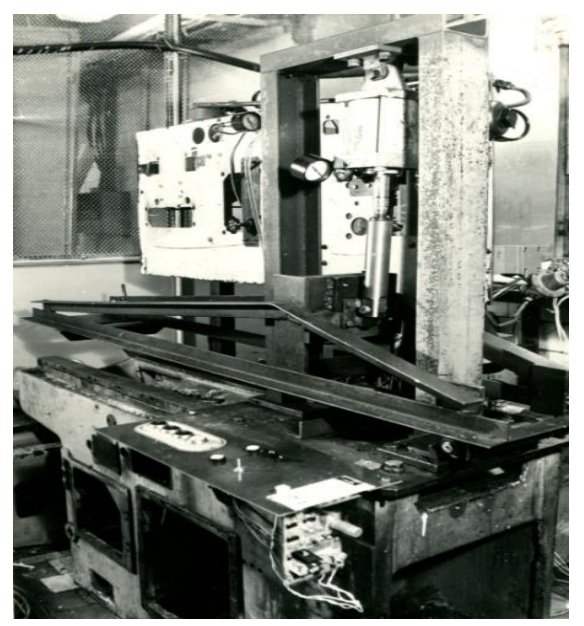

б)

Figure 2 - Diagram of the hydraulic drive (a) and a stand for experimental research (b)

The body of the hydraulic cylinder and its rod were hinged, respectively, with a portal and a frame. Under the influence of the cylinder, the frame rotated around an axis mounted on the base of the portal.

At the end of the frame opposite to the pivot axis, there was a load imitating the mass of the grinding headstock.

The graph of computer simulation of working off the task by the automatic control system at various gain rates $\mathrm{K}_{\mathrm{amp}}$ is shown in Fig. 3. 


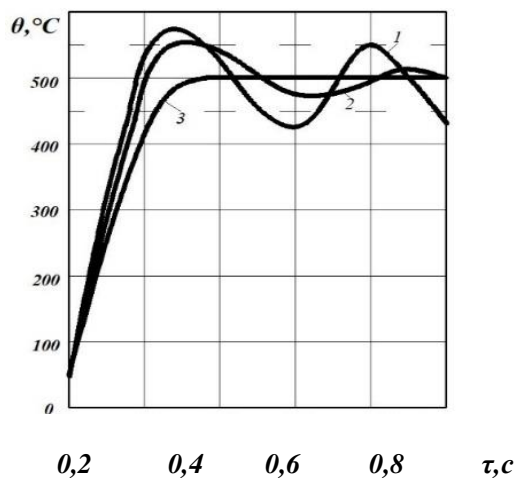

Figure 3 - Computer simulation of the maintenance task constant temperature of slab grinding by an automatic control system with a hydraulic drive:

$$
1-\mathrm{K}_{\mathrm{amp}}=640 ; 2-\mathrm{K}_{\mathrm{amp}}=480 ; 3-\mathrm{K}_{\mathrm{amp}}=320
$$

\section{Results.}

As a result of the study, a model of a system for adaptive control of the temperature of grinding slabs during their cleaning has been proposed. The system under consideration makes it possible to obtain a high-quality surface layer during rough grinding of slabs.

\section{Conclusions.}

Computer simulation has confirmed the operability of the system for maintaining the specified temperature of slab grinding under various operating conditions that simulate the situations of real production.

The use of the system for maintaining the grinding temperature on roughinggrinding machines makes it possible to automate the process of abrasive cleaning, reduce the non-productive consumption of expensive billet metal, and increase the competitiveness of domestic producers of rolled metal products.

References: 1. Chirkov G. V. Matematicheskoe modelirovanie rezhimov rezaniya pri obrabotke materialov abrazivnymi instrumentami. Tekhnologiya mashinostroeniya. - 2004. - N 6. - pp.58-61. 2. Lebedev V., Klimenko N., Uryadnikova I., Chumachenko T., Ovcharenko A. The definition of amount of heat released during metal cutting by abrasive grain and the contact temperature of the surface being grinded. Eastern-European Journal of Enterprise Technologies. 2016. No 5/7(83) 2016. — pp. 43-50. 3. Amitay G, Malkin S, Koren Y. Adaptive control optimization of grinding. trans. The American society of mechanical engineers. Vol. 103, No 1, pp. 131-136, Feb.1981. 4. ACM - Adaptive Control $\&$ Monitoring. Adaptive feed rate control and monitoring. siemens.com 2008 https://assets.new.siemens.com/siemens/assets/api/uuid:9b3f1c78-227b-488b-84cce39127a0fec7/versionvondfmc-b10081-00acmde-72.pdf. 5. Ken Thayer. Grinding theory and adaptive control optimization. Manufacture equipment and accessories. October 5. 2018 
https://insights.globalspec.com/article/10106/grinding-theory-and-adaptive-control-optimization. 6. Xiu-Shou H. The Research of a Practical Adaptive Control System for on External Cylindrical Grinding Process. In: Tobias S.A. (eds) Proceedings of the Twenty-Fifth International Machine Tool Design and Research Conference. Palgrave, London 1985. pp. 169-175. https://doi.org/10.1007/978-1349-07529-4_18. 7. Petrakov Iu.V. Adaptive control system for CNC machine-tools. 2016 Zavershennye nauchno-issledovatelskie raboty https://report.kpi.ua/en/node/1082 8. Larry Haftl. Adaptive Controls Save Tools and Time.Technology Advances Supercharge an Old Process. JAN 23, 2007 https://www.americanmachinist.com/machining-cutting/article/21896290/adaptive-controls-savetools-and-time. 9. Gao Y BSc, MSc, Jones B. Discrete Control System Model for the Traverse Grinding Process. Proceedings of the institution of Mechanical Engineers.Part 1:Journal of Systems and Control Engineering. First Published February 1, 1992, pp. 19-27. 10. Zhan Qi Hu, Ming Li Xie, Yu Kun Li, Yi Tong Zhang. Research on Adaptive Control of Grinding Force of CNC Cams Grinder. Key Engineering Materials (Volume 416) September $2009 . \quad$ pp 360-364. https://doi.org/10.4028/www.scientific.net/KEM.416.360. 11. Mingli Xie; Zhanqi Hu; Yitong Zhang. Research on Adaptive Control of Grinding Force of CNC Cam Grinder. International Workshop on Intelligent Systems and Applications. Wuhan, China. 23-24 May 2009. (DOI: 10.1109/IWISA.2009.5073054). 12. Usov A., Tonkonogyi V., Dašic P., Rybak O. Modelling of Temperature Field and Stress-Strain State of the Workpiece with Plasma Coatings during Surface Grinding. Machines, Switzerland, 2019, 7(1), 20; (DOI: https://doi.org/10.3390/machines7010020).

\author{
Валентин Тихенко, Володимир Лебедєв, \\ Тетяна Чумаченко, Одеса, Україна
}

\title{
АВТОМАТИЧНЕ КЕРУВАННЯ ТЕМПЕРАТУРНО-СИЛОВИМ РЕЖИМОМ ПРИ ОБДИРНОМУ ШЛІФУВАННІ СЛЯБІВ
}

\begin{abstract}
Анотація. Для отримання високоякісного прокату поверхневий шар заготовок (слябів), щчо містить дрібні тріщини, раковини $і$ окалину, повинен бути зачищений прямо в цехах металургійних підприємств. Існують різні способи зачистки слябів, проте пріоритет залишається за обробкою поверхневого шару абразивним кругом на копіювально-иліфувальних верстатах. Формування фізичних властивостей поверхневого шару сляба при обдирному шліфування залежить від температури в зоні контакту круга зі слябом, щяо забезпечує певний фазово - структурний склад і текстуру иього шару, його напружений стан. Температура, щяо виникає в зоні контакту шліфувального круга зі слябом, може становити $1200-1300^{\circ}$ С. Вона $\epsilon$ основною причиною утворення шліфувальних дефектів - глибоких змін фазово - структурного складу поверхневого шару, щч створює сприятливі умови для утворення залишкових напружень $i$ як наслідок - тріщин. При обробчі, через геометричні похибки поверхні сляба, а також через місиеві зміни твердості, відбуваються періодичні коливання миттєвої глибини різання, щцо викликає періодичні зміни величини контактної температури шліфування в результаті чого можуть виникати теплові дефекти поверхневого шару. Інформацію про величину температури можна отримати непрямим шляхом, контролюючи один з технологічних параметрів, наприклад, потужність, затрачену на шліфування, з наступним перерахунком ії в значення температури в режимі опline. Температура шліфування описується як об'єкт управління у вигляді аперіодичної ланки. Комп'ютерне моделювання підтвердило працездатність системи підтримки заданої температури шліфування слябів при різних умовах функціонування, щчо імітують ситуаиї реального виробництва.
\end{abstract}

Ключові слова: обдирне шліфування; управління температурою шліфування слябу; аперіодична ланка. 